\title{
Re-Examining Exchange-Rate Risk Effects and Export Trade Using the ARDL Bounds Testing Approach
}

\author{
Augustine C. Arize $^{1} \&$ John Malindretos ${ }^{2}$ \\ ${ }^{1}$ College of Business and Entrepreurship, Texas A\&M University, USA \\ ${ }^{2}$ Cotsakos College of Business, William Paterson University, USA \\ Correspondence: Augustine C. Arize, College of Business and Entrepreurship, Texas A\&M University, \\ Commerce, Texas 75429, USA. E-mail: Chuck.Arize@tamuc.edu
}

Received: April 8, 2014

Accepted: April 18, 2014

Online Published: June 25, 2014

doi:10.5539/ijef.v6n7p31

URL: http://dx.doi.org/10.5539/ijef.v6n7p31

\begin{abstract}
Previous studies that examined the influence of exchange rate risk on the export flows in Nigeria have not used the Bounds testing technique suggested by Pesaran, Shin and Smith (2001). This paper employs this technique to obtain long-run elasticities as well as understand the forces at work in the short-run adjustment of real exports to changes in foreign economic activity, relative export price and exchange-rate risk. Quarterly data are used, and the period studied is 1980:1 to 2010:4. Results from cointegration analysis, short-run error correction models and persistence profile analysis indicate cointegration and negative effects of exchange rate risks on export volume in both the long run and the short-run.
\end{abstract}

Keywords: exchange-rate risk, ARDL, exports

\section{Introduction}

The main objective of this paper is to empirically examine the influence of exchange-rate volatility on real exports of Nigeria using the Autoregressive distributed lag (ARDL) bounds testing technique of Pesaran, Shin and Smith (2001) (Note 1). Although this technique has grown in popularity among researchers of time series data, to our knowledge, the present study is an initial attempt to delineate the short- and long-run relationships among real exports, economic activity, and exchange-rate volatility in Nigeria using the ARDL technique.

This methodology is accepted as preferable to alternative estimators because the obtained results exhibit good small sample properties and, therefore, can reject a false null hypothesis. Second, it is appropriate, whether the variables are stationary or nonstationary; hence, pre-testing of the time series for unit roots is unnecessary. Third, it obtains both estimates of short- and long run coefficients as well as the variance-covariance matrix jointly, therefore making possible inference on the long-run elasticities, which is not always true under alternative long-run estimation methods. Fourth, it ensures that inference concerning cointegration is made by using critical values of the bounds F-statistic. Fifth, while being a two-step method, it ensures the endogeneity of the regressors.

Besides the methodological points noted above, the effect of exchange rate volatility on export flows is important because, from a policy standpoint, knowledge of the degree to which exchange-rate volatility affects trade is important for the design of both exchange rate and trade policies. For example, if exchange rate volatility leads to a reduction in exports, trade adjustment programs that emphasized export expansion could be unsuccessful if the exchange rate is volatile. In addition, the intended effect of a trade liberalization policy may be doomed by a variable exchange rate and could precipitate a balance-of-payment crisis (Arize, Osang, \& Slottje, 2000).

The features of this paper which separate it from the other papers in this literature are: (1) the cointegration methods employed by previous studies are valid only when the variables are nonstationary. This is unlike the ARDL noted above, which can handle both stationary and non-stationary series; (2) we use of real effective exchange rate (REER) to obtain real exchange-rate volatility. This approach is preferred because it uses a comprehensive measure of movements in the total value of a country's currency since it is obtained using the data of several relevant trading partners (Note 2); (3) we use of conditional standard deviation as a measure of exchange rate volatility obtained from GARCH model (Note 3); (4) the use of estimates and tests of coefficients 
of the cointegrating relations is based not only on the ARDL approach. For comparison reasons, we report those of five alternative estimators. We report estimates and tests of estimated coefficients obtained from the multivariate cointegration method of Johansen (1995), the dynamic least squares (DLS) estimator of Stock and Watson (1993), the fully modified least squares (FMLS) of Phillips and Hansen (1990), the instrumental variable estimator of Bewley (1990) and Wickens and Breusch (1988) and the canonical cointegrating regression (CCR) of Park and Choi (1988); (5) the tests of cointegration are based not only on the bounds test of ARDL approach but also the Harris and Inder (1994) test.

The results of Monte Carlo analysis suggest that the Harris and Inder procedure is powerful and can serve as a cross-check for cointegration of real exports and exchange-rate volatility (Note 4); and (6) the use of persistence profile, a system-wide measure developed by Pesaran and Shin (1996) which unlike the standard approach does not require any strong exogeneity property of the variables involved and gives information on the shape of the whole adaptation path.

The structure of the study is organized in the following manner: Section 2 describes the theoretical connection between exchange rates and real exports with a brief overview of two alternative measures of exchange rate volatility; section 3 describes the export demand model and reports the results; and a brief conclusion is presented in section 4. The data used is from 1980:1 through 2010:4.

\section{Exchange-Rate Volatility and Export Demand}

Theoretically, the effect of exchange-rate risk on trade flows can be negative or positive. A higher exchange-rate volatility leads to higher cost for risk-averse traders and also to less foreign trade. This is because the exchange rate is agreed on, at the time of the trade contract, but payment is not made until the future delivery actually takes place. If exchange rate changes become unpredictable, this creates uncertainty about the profits to be made, and hence, reduces the benefits of international trade. The exchange-rate risk for developing countries is generally not hedged because forward markets are not accessible to all traders. Even if hedging in the forward markets were possible, there are limitations and costs. For example, the size of the contracts is generally large, the maturity is relatively short, and it is difficult to plan the magnitude and timing of all their international transactions to avail themselves of the forward markets (Arize, Osang, \& Slottje, 2000, 2008; Arize, 1997, 1995).

On the other hand, recent theoretical analysis indicates that the effect of exchange rate volatility could be positive. One assertion is that the degree of risk aversion is important in determining the impact of exchange-rate volatility on trade. For example, De Grauwe (1988) has stressed that the dominance of income effects over substitution effects can lead to a positive relationship between trade and exchange-rate volatility. This is because, if exporters are sufficiently risk-averse, an increase in exchange-rate volatility raises the expected marginal utility of export revenue and therefore induces them to increase exports. He suggests that the effects of exchange-rate uncertainty on exports should depend on the degree of risk aversion. A very risk-averse exporter who worries about the decline in revenue may export more when risks are higher. On the other hand, a less risk-averse individual may not be concerned with the worst possible outcome and, considering the return on export less attractive, may decide to export less when risks are higher.

Baldwin and Krugman (1989, p. 635) and Dixit (1989, p. 206) have argued that sunk entry and exit costs can also influence foreign trade. Briefly, firms have to invest before they can sell their goods in another country. Some of the investments may be in research and development, relocation and distribution systems, and capital investment. The cost of these investments cannot be recouped if the firm decides to stop the export activities to a particular country. As the exchange rate becomes more volatile, firms will tend to wait longer, widening the interval in which neither exit nor entry occurs. That is, sunk or entry costs produce hysteresis in trade flows. As with 'risk aversion' models, it is not always clear how trade will be affected. Further, Froot and Klemperer (1989, p. 643) showed that exchange-rate uncertainty can affect the price and quantity of trade, either positively or negatively, when market share matters under an oligopolistic market structure, regardless of risk choices.

Bailey and Tavlas (1988) and Tavlas and Swamy (1997) have provided reasons why the effect of exchange-rate risk on foreign trade could be positive. The authors argue that if traders gain knowledge through trade enabling them to anticipate changes in the exchange rate better than the average participant in the foreign exchange market, they can profit from this knowledge. That profit may offset the risk represented by movements in the exchange rates. The earned income from using such knowledge in the foreign-exchange market may offset the risk represented by movements in the exchange rate. They point out that, in any fast changing business environment, price-affecting information is scarce and valuable, and these traders are likely to have proprietary access to some of it.

From the above discussion, we gather that exchange rate volatility is a basis of anxiety because the currency 
values help determine the price paid or received for output and, hence, it affects the profits and welfare of market participants. Overall, it is clear that theory alone cannot determine determine the sign of the relation between foreign trade and exchange rate volatility.

Before presentation of the model, it is necessary to derive an operational measure of exchange-rate volatility. Here, our proxy of real exchange rate volatility is obtained with the idea that real exchange rate follows a GARCH process.

\section{Univariate GARCH Model.}

The conditional variance of a time series in the GARCH model depends upon the squared residuals of the process and has the advantage of incorporating heteroscedasticity into the estimation procedure of the conditional variance (Bollerslev, 1986). The predictable component of volatility is the conditional variance of a series from a GARCH model. For our purpose, we use the following models:

$$
\begin{gathered}
\text { REER } R_{t}=f_{0}+f_{1} \text { REER }_{t-1}+u_{t} \\
\text { where } u_{t} \sim \mathrm{N}\left(0, h_{t}^{2}\right) \\
h_{t}^{2}=d_{0}+d_{1} \varepsilon_{t-1}^{2}+d_{2} h_{t-1}^{2}
\end{gathered}
$$

Where the conditional variance of equation (3) is a weighted average of a long-term average of mean or the constant term, the ARCH term represented by $\varepsilon_{t-1}^{2}$, and the GARCH term is captured by the $h_{t-1}^{2}$. The predicted values of the regressand in (3) measures the volatility of of real exchange rate, whereas, the square root is the conditional standard deviation, which is used as an independent variable in our demand for export equation.

The second measure we experimented with is a time-varying measure of exchange-rate volatility, which accounts for periods low and high exchange-rate uncertainty. It is constructed by the moving average of the standard deviation of the REER and is expressed as

$$
J_{t+m}=\left[\frac{1}{m} \sum_{i=1}^{n}\left(R_{t+i-1}-R_{t+i-2}\right)^{2}\right]^{\frac{1}{2}}
$$

Where $\mathrm{R}$ is the natural logarithm of the real effective exchange rate, and $\mathrm{m}=8$ is the order of the moving average (see Arize et al., 2000).

\section{Model Specification and Empirical Methodology}

Following Arize, Osang, and Slottje (2000), the long-run export demand can be written as:

$$
X_{t}^{*}=\propto_{0}+b \cdot w_{t}+c \cdot P_{t}+d \cdot \sigma(h)_{t}+z_{t}
$$

where $X_{t}^{*}$ denotes the logarithm of desired real exports, $w_{t}$ is the logarithm of a measure of foreign economic activity; $P_{t}$ is the logarithm of export price in U.S. dollars relative to trade-weighted foreign prices; $\sigma(h)_{t}$ is a measure of exchange-rate uncertainty; and $z_{t}$ is a disturbance term.

If foreign economic activity rises, the demand for exports will rise, the estimated coefficient $(\hat{b})$ is expected to be positive. On the other hand, if relative prices rise, the demand for exports will fall, so $\hat{c}$ is expected to be negative. As noted earlier, the sign on $\hat{d}$ is expected to be negative or positive. To make the equation (5) estimable, we need to replace the desired export demand with actual (observable) level (i.e., $X_{t}^{*}=X_{t}$ ). To allow for the adjustment of real exports to changes in the regressors, the short-run relationship is based on estimating an unrestricted Error correction model (UECM) for the desired real exports which may be written as:

$$
\begin{aligned}
\Delta x_{j, t}=a+\varphi D_{t}+ & \sum_{i=1}^{k} b_{i} \Delta x_{j, t-i}+\sum_{i=0}^{k} c_{i} \Delta w_{t-i}+\sum_{i=0}^{k} d_{i} \Delta p_{j, t-1}^{*}+\sum_{i=0}^{k} \pi_{i} \Delta \sigma(h)_{j, t-i} \\
& +\delta_{1} x_{j, t-1}+\delta_{2} w_{t-1}+\delta_{3} p_{j, t-1}+\delta_{4} \sigma(h)_{j, t-1}+\mu_{1}
\end{aligned}
$$

where $\Delta X_{t}, \Delta W_{t}, \Delta P_{t}^{x}$ and $\Delta \sigma(h)_{t}$ are the first differences of the logarithms of the real income, foreign economic activity, relative export price and exchange-rate volatility, respectively. In a similar fashion, the coefficients $b_{i}, c_{i}, d_{i}$, and $\pi_{i}$ represent the short-run dynamics of the underlying variables in the ARDL model, and the coefficients $\delta_{1}, \delta_{2}, \delta_{3}$ and $\delta_{4}$ represent the long-run relations. Since we are normalizing on real exports, the long-run elasticities are the coefficients of the explanatory variables lagged one period (multiplied by a negative sign) divided by the coefficient of the regressand also lagged one period. Thus, the long run elasticities for foreign economic activity, relative export price, and exchange-rate risks are $\left(-\delta_{2} / \delta_{1}\right),-\left(-\delta_{3} / \delta_{1}\right)$, and $-\left(\delta_{4} / \delta_{1}\right)$, respectively (Bardsen, 1989). The standard errors are obtained using the delta approach. Prior to estimation, two dummy variables were entered in equation (6) (Note 5). The blip binary variables proxy the behavior of the economy during the 1986-1999 period, and the two dummies were both treated as exogenous 
variables.

Before implementing the ARDL bounds testing technique, it is necessary to establish the number of lags on each first-differenced variable in equation (6). The Akaike Information Criterion (AIC) and autocorrelation test were used to determine the number of lags. The maximum lag of four was used. For further analysis, the stability of equation (6) was determined using the Dufour as well as Hansen approaches.

In sum, recall that under the ARDL bounds testing approach, the null hypothesis of no cointegration is tested against the alternative hypothesis of cointegration. To check the sensitivity of our cointegration test, we have implemented the Harris and Inder test (discussed below), where the null hypothesis is the presence of cointegration. This is in line with the specification suggestion by Gregory (1994) noted earlier. Implementing two cointegration tests which are based on different null hypotheses might lend credence to our results. The Harris-Inder cointegration test is described below.

\section{Harris-Inder Cointegration Test.}

The Harris and Inder cointegration test requires testing the null hypothesis of cointegration against the alternative hypothesis of no cointegration. This approach uses the Engle-Granger two-step method and the Kwiatkowski, Philips, Schmidt, and Shin (1992; KPSS) unit root. The Harris-Inder approach is specified as ${ }^{6}$

$$
\begin{gathered}
y_{t}=z_{t}^{\prime} \gamma_{0}+\tau+\epsilon_{t}, \epsilon_{t} \sim I N\left(0, \sigma^{2}\right) \\
z_{t}=z_{t-1}+\eta_{t} \\
\tau_{t}=\tau_{t-1}+w_{t}, w_{t} \sim I N\left(0, \sigma_{w}^{2}\right)
\end{gathered}
$$

where $\mathrm{y}_{\mathrm{t}}$ is the dependent variable, $\mathrm{z}_{\mathrm{t}}$ is a vector of nonstationary regressors and $\tau_{t}$ is a random walk in the residuals of the cointegrating equations (i.e., equation 7). If a random walk component exists in the residuals of equation (7) and equations (8) through (9) captures the correct data-generating process, then the variables will not be cointegrated. Nevertheless As suggested by Harris and Inder, testing the null hypothesis of $\sigma_{w}^{2}=0$ against the alternative null $\sigma_{w}^{2}>0$ will test the null hypothesis of cointegration against the alternative of no cointegration. In sum, the first step of this test is to obtain residuals of equation (5) and then apply the KPSS test to the residuals to see if a unit root exists. To summarize, the Harris-Inder testing approach uses nonparametric correction and the critical values are given in Harris and Inder (1994).

\section{Empirical Results}

\subsection{Data and Variable Definitions}

The empirical analysis uses the quarterly frequency data for Nigeria. The observations covering the period 1980:1 through 2008:4 were used as the estimation period, whereas, the data from 2009:1 to 2010:4 were used as the forecast period. The data are taken from the IMF's International Financial Statistics (2010) CD-ROM, IMF's Central Statistics office, and the IMF's Directions of Trade (DOT) statistics, Economic Intelligence Unit (EIU) database of the Economist and World Tables (World Bank, 2006) and OECD Main Economic Indicators. All variables are in the logarithms.

Real exports are measured in US dollars and were constructed as (nominal exports deflated by the unit value of exports. Foreign economic activity is measured by the advanced countries industrial production with 2005 as the base year. Export price data for Nigeria are not readily available and therefore require using data from two sources. Therefore, it was obtained by splicing approach, where we used data from the World Tables (World Bank, 2002), and collected the rest from the Economic Intelligence Unit (EIU) database of the Economist. Given that the export price data were in annual format, to obtain quarterly series, we applied a quadratic interpolation method outlined and used in Bergstrom (1990). The procedure is clearly described in Arize et al. (2005), and the base period is $2005=100$.

The relative export price index is Nigeria's unit value of exports deflated by advanced economies consumer price index from IFS. We experimented with a geometric trade-weighted average of export prices or unit value of exports of thirteen major trading partners (Australia, Canada, France, Germany, Hong Kong, India Italy, Japan, Korea, the Netherlands, Pakistan the United Kingdom and the United States). The weights are $w_{j i}$, and the base period is $2005=100$.

To compute measures for exchange-rate volatility, trade-weighted effective exchange rate (eer) and real effective exchange rate (reer) were computed. They were constructed as follows (for illustrative purposes, let Nigeria be country $j$ ). The period average exchange rates are in units of domestic currency per dollar. These period averages were then expressed in index form (2005=1.0). The eer variable was calculated as: $\operatorname{EXP}\left[\Sigma w_{j i} \operatorname{In} E(I, \$, t)-\operatorname{In} E(j\right.$, $\$, t)]$ where $\mathrm{EXP}=$ exponent, $\mathrm{In}=$ natural logarithm, $E(I, \$, t)=$ exchange-rate index of country $\mathrm{i}$ at time $\mathrm{t}$ and $E(j$, 
$\$, t)=$ exchange-rate index of Nigeria at time $t$. The real effective exchange rate was calculated as: $R E E R(j$, $t)=\operatorname{EXP}\left[-\operatorname{In} P(j, t)+\Sigma w_{j i} \operatorname{In} P(i, t)-\Sigma w_{j i} \operatorname{In} E(i, \$, t)\right]$ where the exchange rate terms are in units of country $i$ (or $j$ ) currency per U.S. dollars in index form $(2005=1.0)$. $\mathrm{P}$ is the consumer price index of country $i$ (or $j$ ) in index form $(2005=1.0)$. Our GARCH $(1,1)$ is reported below with t-values in parentheses below each estimated coefficient:

$$
\begin{gathered}
\text { REER }_{t}=1.26+0.98284 \text { REER }_{t-1} \\
(0.42) \quad(35.99) \\
h_{t}^{2}=5.814+0.0161 d_{1} e_{t-1}^{2}+0.932 h_{t-1}^{2}
\end{gathered}
$$

\subsection{Unit Roots}

Statistical inference from time series is usually based upon the assumption of stationarity. Since the common practice is to use the augmented Dickey-Fuller (ADF) test, the results are reported in Table 1. From these results

\begin{tabular}{|c|c|c|c|c|}
\hline \multirow[t]{2}{*}{ Variables } & \multirow[b]{2}{*}{ Lags } & \multicolumn{2}{|c|}{$A D F H_{0}: J_{t} \sim I(1) \quad H_{a}: J_{t} \sim I(0)$} & \multirow[t]{2}{*}{ Difference } \\
\hline & & w/o trend & $w$ trend & \\
\hline Real Exports $\left(X_{t}\right)$ & $1-8$ & -2.15 & -2.22 & -3.74 \\
\hline World Activity $\left(W_{t}\right)$ & $1-8$ & -2.29 & -2.55 & -2.72 \\
\hline Relative price $\left(P_{t}\right)$ & $1-8$ & -1.86 & -2.46 & -3.13 \\
\hline GARCH $\sigma\left(h_{t}\right)$ & $1-8$ & -2.72 & -2.75 & -3.31 \\
\hline Moving Standard Deviation $\sigma\left(h_{t}\right)^{*}$ & $1-8$ & -2.71 & -3.02 & -4.85 \\
\hline CV & & -2.89 & -3.45 & -2.89 \\
\hline
\end{tabular}
in Table 1, we gather that the variables can be taken as nonstationary.

Table 1. Augment dicky-fuller unit root tests

Note. The critical value (CV) of the ADF statistic is -2.89 for zero-trend, and trend is included, it is -3.45 at the 5 percent level.

To obtain the results of the ARDL model, requires two stages. For the first stage, an F-test is used to examine the joint significance of the estimated coefficients on the level variables in equation (1). The null hypothesis is that all the coefficients of the long-run relation are jointly equal to zero (i.e., no cointegration) against the alternative hypothesis that estimated coefficients are not jointly significantly different from zero (i.e., cointegration). In the second stage, the parameters of the ARDL model and their long-run coefficients are obtained.

\subsection{Bounds Testing for the Level Relations}

First, equation (6) is estimated by Ordinary Least Squares (OLS) and then the level terms are excluded from the model by variable deletion test to determine their joint statistical significance. The obtained F-statistic for the hypothesis that $\delta_{1}=\delta_{2}=\delta_{3}=0$ in the model with real exports $\left(x_{t}\right)$ as regressand is indicated by $\mathrm{F}\left(x_{t} \mid w_{t}, p_{t}, \sigma(h)_{t}\right)$, where $w_{t}$ is foreign economic activity, $p_{t}$ is relative export price and $\sigma(h)_{t}$ is a measure of exchange-rate risk. Then, the same steps are followed in the specification with $w_{t}, p_{t}$, or $\sigma(h)_{t}$ as the regressand. That is, in our case three other regressions are run. The estimated F-statistic for the hypothesis that $\delta_{l}=\delta_{2}=\delta_{3}=0$ in the latter specifications are denoted by $\mathrm{F}\left(w_{t} \mid x_{t}, p_{t}, \sigma(h)_{t}\right), \mathrm{F}\left(p_{t} \mid x_{t}, w_{t}, \sigma(h)_{t}\right)$ or $\mathrm{F}\left(\sigma(h)_{t} \mid x_{t}, w_{t}, p_{t},\right)$.

The test's critical values are nonstandard, and rely on Monte Carlo results reported in Pesaran, Shin and Smith (2001). Then, in order to reject the null of no cointegration, the computed F-value is compared to the F critical values suggested by Pesaran, Shin and Smith (2001). For instance, if the computed F-value is higher than the upper bound of the critical values reported in Pesaran, Shin and Smith (2001), the null hypothesis is rejected. However, if the computed F-statistic falls between the lower and the upper bounds, the test is inconclusive. Further, a fail-to-reject decision of the null of no cointegration obtains if the computed $\mathrm{F}$ falls below the lower bound. 
Table 2. Cointegration test results. f-statistics for cointegration relationship

\begin{tabular}{lcccc}
\hline Critical value bounds of the $F$-statistic & \multicolumn{3}{c}{$95 \%$ level } \\
& $\mathrm{I}(0)$ & $\mathrm{I}(1)$ & $\mathrm{I}(0)$ & $\mathrm{I}(1)$ \\
& 2.721 & 3.773 & 3.232 & 4.351 \\
\hline Calculated F-Statistics & & & & \\
$\mathrm{F}\left(x_{t} \mid w_{t}, p_{t}, \sigma(h)_{t}\right)=6.201 *$ & & & & \\
$\mathrm{~F}\left(w_{t} \mid x_{t}, p_{t}, \sigma(h)_{t}\right)=2.301$ & & & & \\
$\mathrm{~F}\left(p_{t} \mid x_{t}, w_{t}, \sigma(h)_{t}\right)=2.519$ & & & & \\
$\mathrm{~F}\left(\sigma(h)_{t} \mid x_{t}, w_{t}, p_{t},\right)=3.770$ & & & & \\
\hline
\end{tabular}

Notes. An * indicates statistical significance at the $5 \%$ and $10 \%$ level. The absolute values of t-ratios are in parentheses. The relevant critical values are obtained from Table C1.iii (with an unrestricted intercept and no trend with three regressors) in Perasan et al., (2001). The optimal lag length is four. An *Indicates the statistical significance at the conventional level.

Starting with results from $\mathrm{F}\left(x_{t} \mid w_{t}, p_{t}, \sigma(h)_{t}\right)$ in Table 2, the null hypothesis that $\delta_{1}=\delta_{2}=\delta_{3}=0$ (no cointegration) is rejected in favor of cointegration because 6.201 exceeds the upper limit of the critical band (see Table 2 for details). This shows cointegration among $x_{t}, w_{t}, p_{t}$, and $\sigma(h)_{t}$, when normalization is on real exports. For the $\mathrm{F}\left(w_{t} \mid x_{t}, p_{t}, \sigma(h)_{t}\right)$, it is observed that the computed F-value is 2.301 is below the lower limit of the critical band at the $90 \%$ and $95 \%$, respectively. This finding implies that the hypothesis of no cointegration cannot be achieved with foreign economic activity as the regressand. In a similar fashion, the results for both $\mathrm{F}\left(p_{t} \mid x_{t}, w_{t}, \sigma(h)_{t}\right)[=2.519]$ and or $\mathrm{F}\left(\sigma(h)_{t} \mid x_{t}, w_{t}, p_{t},\right)[=3.770]$ support the null hypothesis of no cointegration. Hence, the null hypothesis that the level variables do not enter significantly in the equations for $\Delta w_{t}, \Delta p_{t}$, and $\Delta \sigma\left(h_{t}\right)$, suggest that foreign economic activity, relative export price and exchange-rate risks are statistically considered as "long-run forcing" variables that assist in explaining of real exports.

Table 3. Regression results of the error-corrections model

\begin{tabular}{|c|c|c|c|c|c|c|}
\hline \multicolumn{7}{|c|}{ Variables } \\
\hline Selection Method & Lag & $e c_{t}$ & $w_{t}$ & $p_{t}$ & $\sigma\left(\boldsymbol{h}_{t}\right)$ & Summary Statistics \\
\hline \multirow{6}{*}{$\begin{array}{c}\text { AIC } \\
(1,0,1,0)\end{array}$} & 0 & & 1.12 & -0.54 & -0.96 & $\overline{\mathrm{R}}^{2}=0.85 \quad \mathrm{DW}=1.95$ \\
\hline & & & $(4.19)$ & $(4.06)$ & $(3.72)$ & Serial Corr. $F[4,95]=0.961$ \\
\hline & & & & & & NORMALITY $\chi^{2}(2)=11.59 *$ \\
\hline & 1 & -0.34 & & & & Ramsey $\chi^{2}(1)=1.25$ \\
\hline & & $(4.99)$ & & & & HET $\chi^{2}(1)=0.67$ \\
\hline & & & & & & Dufour $F[12,87]=1.656$ \\
\hline
\end{tabular}

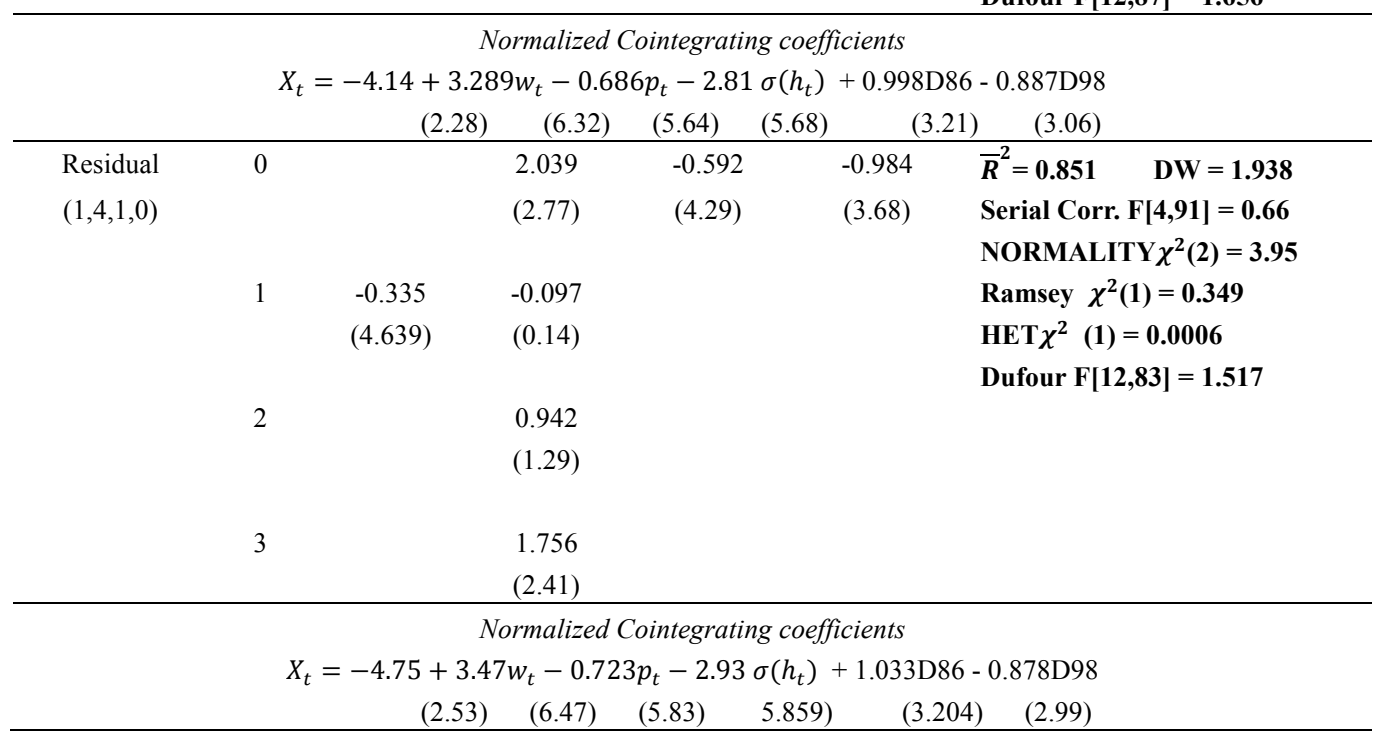

Note. The dummy variable D86 is coded as -1 in the first and fourth quarters of 1986 and 1 in the first and second quarters of 1994 , respectively and zero otherwise. D98 is coded as one in third and fourth quarters of 1998 and -1 in the second and third quarters of 1999 , respectively and zero otherwise. The critical values for the $\chi^{2} \mathrm{~s} 5.99$ at the 5 percent level, whereas it is 4.10 at the $10 \%$ level. 
Before discussing our long-run elasticities, we note that our finding of cointegration among real exports, foreign economic activity, relative export price and exchange-rate risk is supported by the Harris-Inder method. The obtained value is 0.164 , whereas, the critical value is 0.3203 at the 5 percent level. Also, both Johansen statistics and persistence profile corroborate our finding of cointegration. These results are reported in the Appendix. Without discussing in details, the results indicate, not only the presence of cointegration but also the presence of a single cointegrating relation.

Having provided evidence concerning cointegration and some relevant hypotheses, it seems prudent to examine the long-run elasticities. The long-run elasticities are reported as normalized cointegration coefficients in Table 3 . Some key points are highlighted by the results. First, from Table 3 we gather that the demand relationship is estimated to be positive and elastic for foreign economic activity, whereas, for relative price it is negative and inelastic. In the case of exchange- rate risk, it is negative and elastic.

Second, the estimated foreign activity elasticity implies a fairly large response of exports to changes in foreign economic activity. This result is similar to 3.274, reported in Onafowora and Owoye (2008). Our results suggest that in the long-run, an increase of one percent, on average, leads to 3.447 percent increase in real exports. There are several explanations for the relatively high foreign activity elasticities. Riedel (1988) notes that most available income elasticities in export demand equations, "whether in developed or developing countries, or for country aggregates or in individual countries generally lie in the range between 2.0 and 4.0." Of the six studies surveyed in Marquez and McNelly (1988, Table 1, p. 307) four report income elasticities greater than two and three report elasticities greater than three. Arize, Osang, and Slottje (2000) report long run elastities greater than unity in all countries, greater than two in ten out of thirteen countries and greater than three in six countries.

Riedel $(1988,1989)$ conjectures that the high elasticities found in the literature reflect the inadequate treatment of both the supply side of exports and the normalization issue. His estimate of a simultaneous equation model with export demand normalized as a price equation yields a lower income elasticity. For a critique of Riedel's approach, see Nguyen (1989) as well as Muscatelli, Srinivasan and Vines (1992), among others. A different explanation for high income elasticities has been given in Arize (1990). He argues that an increased penetration of world markets over the sample period can, in part, be attributed to income elasticities of developing countries being a function of the foreign activity elasticities of the importing countries. This is plausible if exports are largely composed of semi-finished products which are used to produce final products in other countries. Finally, Adler (1970) has suggested that different income elasticities reflect the extent to which exports have been adapted to the importing country's local tastes, with higher elasticities providing evidence of greater adaptation.

Third, our estimated price elasticity of -0.723 differs markedly from the -1.163 reported by Onafowora and Owoye (2008). They report a standard error of 5.991 which makes their estimated price elasticity statistically insignificant (i.e., a t-value of -0.194) at the conventional levels. Our elasticity of -0.723 indicates that, ceteris paribus, an increase of one percent leads to a decrease in real exports of about 0.723 percent. Because this elasticity is less than one, the response of real exports to relative price is inelastic. Fourth, our exchange-rate volatility elasticity is consistent with their conditional variance of -17.195. In this study, we have used conditional standard deviation and obtained an elasticity of -2.93 (Note 7). That is, other things being equal, if exchange rate risk increases by one percent, a decrease in exports of 2.91 percent is expected (Note 8). A persuading aspect of our results is that all our three regressors (foreign activity, relative price and exchange-rate risk) are statistically significant at the 5 percent level. Another desirable aspect of our results is that the sign, magnitude and significance of our long-run elasticities are similar to those obtained using five alternative estimators. These results are reported in Appendix.

\subsection{Speed of Adjustment and Half-Life}

This section provides information on the speed of adjustment to equilibrium and identifies how quickly real exports respond to changes in the determinants. For brevity of presentation, we focus on the estimates obtained using the Breusch-Godfrey residual correlation test (see ARDL $(1,4,1,0)$ in Table 3 ). The estimated long-run coefficient can be used to obtain an error-correction term by replacing the linear combination of the lagged level of the variables in the ARDL model by $\mathrm{ec}_{\mathrm{t}-1}$, the model is re-estimated by imposing the same lag structure as noted above. Cointegration can be inferred by a negative and statistically significant coefficient on $\mathrm{ec}_{\mathrm{t}-1 .}$. The t-ratio is -4.64 is less than 5 percent critical value of -3.83 computed as in Kremers et al. (1992). Therefore, no cointegration is rejected. Also, since the model includes first-differenced variables, the specification allows for the possibility that the movements in the regressors in any quarter can be related to the previous quarter's gap from the long-run equilibrium.

A significant $\mathrm{ec}_{\mathrm{t}-1}$ means that some type of adjustment must occur whenever real exports deviate from its 
long-term values to restore the equilibrium in the next period. The speed of adjustment is represented by the absolute value of the coefficient on the error-correction term (that is, 0.33) and implies that a deviation from long-run equilibrium following a short-term shock has corrected by 33 percent after a quarter. That is, the adjustment of real exports to changes in the regressors may take about one year. Fifth, our coefficient on the error-correction term of -0.335 is similar to -0.34 reported by Onafowora and Owoye (2008). Both are statistically significant at the 5 percent level.

Do above results change over the period 1980:2 to 2010:4? According to the Dufour test statistic, structural stability is supported in the sample. The computed F-value of 1.656 is not statistically significant at the 5 percent level. The critical value is 2.1. Also, we implement Hansen (1992) joint parameter nonconstancy and variance nonconstancy (JT and VAR) test for stationary data. The computed variance test which is 0.255 and it is less than the article value of 0.353 , the JT test is 4.1 , whereas, the critical value at the 10 percent level is 4.22 . Finally, note that the test statistics for serial correlation, abnormal residuals, non-zero disturbance mean, hetroskedasticity and predictive failure are all satisfactory.

Another important question is what is the plausible explanation for the differences in our results with earlier evidence in Onafowora and Owoye (2008)? First, besides their use of a short sample period from 1980 through 2001, they included a shift term (Note 9) in their cointegration vector while our results suggest that blip dummies are relevant. Second, they used volatility from bilateral exchange rate, but our results indicate that REER is more appropriate.

\section{Summary and Conclusions}

In this paper, best-practice econometric techniques have been used to investigate empirically the long-run and the short-run impact of REER volatility on real export demand. This paper has used GARCH model and employed ARDL estimator to obtain long-run and short-run estimates. We have undertaken a comprehensive array of other cointegration estimators. Results obtained from ARDL cointegration analysis suggest that there exists a stationary long-run equilibrium relationship among real exports, foreign economic activity, relative export price and real exchange rate volatility. The sign, magnitude and significance of the long-run elasticities with respect to export demand are consistent with the economic theory. A key feature of the results is that the exchange-rate volatility is found to have negative effects in the short-run and the long-run. Another important result is that, although foreign economic activity has a greater effect on real export demand, it is relative export price as well as the exchange-rate volatility that have immediate short-run effects on export volume.

Our results suggest that exchange-rate volatility considerations are important when modeling export behavior in Nigeria. It is possible, therefore, that risk-averse exporters will reduce their activities, switch sources of supply and demand, or change prices in order to minimize their exposure to the effect of exchange risk. This, in turn, can alter the distribution across sectors of the economy. For these reasons, the design and implementation of trade and exchange-rate policies in Nigeria should benefit from knowledge of both the existence and the degree of exchange rate volatility. As emphasized by Arize, Osang and Slottje (2000), policy actions aimed at stabilizing the export market are likely to generate uncertain results, if policymakers ignore the stability, as well as the level, of the real exchange rate. Empirical evidence by Arize, Malindretos and Nippani (2004) suggests that exchange rate variability tends to feed inflation in developing economies at a much faster rate than in advanced countries. Therefore, given the high rate of inflation in Nigeria, exchange rate policy by itself would not eliminate exchange-rate volatility; therefore, policy makers should pay attention to fiscal policy. Nigeria needs to improve its external competitiveness to assist the world demand for its exports. The evidence suggests that trade polies, in the face of continuing large trade deficits may not fare well if no adequate attention is given to the likely impact of the exchange rate volatility on each trading partner. Greater attention should be given to export diversification. Improvements in the country's infrastructures, including power supply, would inspire more confidence in exporting activities.

\section{References}

Adler, M. F. (1970). The Relationship Between the Income and Price Elasticities of Demand for United States Exports. Review of Economics and Statistics, 52, 313-319. http://dx.doi.org/10.2307/1926300

Arize, A. C. (1990). An Econometric Investigation of Export Behavior in Seven Asian Developing Economies. Applied Economics, 22, 891-904. http://dx.doi.org/10.1080/00036849000000027

Arize, A. C. (1995). The Effects of Exchange-Rate Volatility on U.S. Exports: An Empirical Investigation. Southern Economic Journal, 62, 34-43. http://dx.doi.org/10.2307/1061373

Arize, A. C. (1997). Conditional Exchange-Rate Volatility and Foreign Trade from Seven Industrialized 
Countries. Southern Economic Journal, 64, 235-254. http://dx.doi.org/10.2307/1061049

Arize, A. C., Malindretos, J., \& Nippani, S. (2004). Variations in Exchange rate and Inflation in 82 countries: An Empirical Investigation. North American Journal of Economics and Finance, 15, 227-247. http://dx.doi.org/10.1016/j.najef.2003.12.002

Arize, A. C., Osang, T., \& Slottje, D. J. (2000). Exchange-Rate Volatility and Foreign Trade: Evidence from Thirteen LDCs. Journal of Business and Economic Statistics, 18, 10-17. http://dx.doi.org/10.2307/1392132

Arize, A. C., Osang, T., \& Slottje, D. J. (2008). Exchange-Rate Volatility in Latin America and its Impact on Foreign Trade. International Review of Economics and Finance, 17, 32-44. http://dx.doi.org/10.1016/j.iref.2006.01.004

Bailey, M. J., \& Tavlas, G. S. (1988, Spring). Trade and Investment Performance under Floating Exchange Rates. The U.S. Experience. IMF Working Paper (37).

Bailey, M. J., Tavlas, G. S., \& Ulan, M. (1987). The Impact of Exchange-rate Volatility on Export Rates: Some Theoretical Consideration and Empirical Results. Journal of Policy Modelling, 9, 225-234. http://dx.doi.org/10.1016/0161-8938(87)90010-X

Bailey, M. J., Tavlas, G. S., \& Ulan, M. (1987). The Impact of Exchange-rate Volatility on Export Rates: The U.S. Experience. IMF Working Paper (37).

Baldwin, R., \& Krugman, P. (1989). Persistent Trade Effects of Large Exchange Rate Shocks. Quarterly Journal of Economics, 104, 635-665. http://dx.doi.org/10.2307/2937860

Bardsen, G. (1989). Estimation of a Long-run Coefficient in Error-correction Models. Oxford Bulletin of Economics and Statistics, 51, 345-350. http://dx.doi.org/10.1111/j.1468-0084.1989.mp51003008.x

Bergstrom, A. R. (1990). Continuous Time Econometric Modeling. Oxford: Oxford University Press.

Bewley, R. A. (1990). Why are Long-run Parameter Estimates so Disparate? The Review of Economics and Statistics, 72(2), 345-349. http://dx.doi.org/10.2307/2109726

Bollerslev, T. (1986). A Conditionally Heteroskedastic Time Series Model for Speculative Prices and Rates of Return. The Review of Economics and Statistics, 69(35), 542-547.

CBN. (2007). The Extent of Naira Exchange Rate Misalignment. Research and Statistics Department, Central Bank of Nigeria, Abuja.

CBN. (2008). The Changing Structure of the Nigerian Economy and Implications for Development. Research Department, Central Bank of Nigeria, Abuja.

De Grauwe, P. (1988). Exchange Rate Volatility and the Slowdown in Growth of International Trade. IMF Staff Papers, 35, 65-84.

Dixit, A. (1989, June). Entry and Exit Decisions Under Uncertainty. Journal of Political Economy, 97, 620-638. http://dx.doi.org/10.1086/261619

Engle, R. F. (1983, August). Estimates of the Variance of U.S. Inflation Based upon the ARCH Model. Journal of Money, Credit and Banking, 286-301. http://dx.doi.org/10.2307/1992480

Froot, K. A., \& Klemperer, P. (1989). Exchange Rate Pass-through When Market Share Matters. American Economic Review, 79, 637-654.

Gregory, A. W. (1994, July). Testing for Cointegration in Linear Quadratic Models. Journal of Economics and Economics Statistics, 12(3), 347-360. http://dx.doi.org/10.2307/1392091

Hargreaves, P. C. (1994). Non-Stationary Time Series Analysis and Cointegration. Oxford: Oxford: University Press.

Harris, D., \& Inder, B. (1994). A Test of the Null Hypothesis of Cointegration In C. Hargreaves (Ed.), Nonstationary Time Series Analysis and Cointegration (pp. 133-152). Oxford University Press.

Hossain, A. A. (2009). Modeling of Narrow Money Demand in Australia: An ARDL cointegration Approach, 1970-2009. Empirical Economics, 42, 767-790. http://dx.doi.org/10.1007/s00181-011-0452-5

Inder, B. (1993). Estimating Long-run Relationships in Economics: A Comparison of Different Approaches. Journal of Economic and Statistics, 57, 53-68.

International Monetary Fund. (2010). International Financial Statistics. CD-ROM. Washington D. C. 
Johansen, S. (1995). Likelihood-based Inference in Cointegrating Vector Autoregressive Models. New York, NY: Oxford University Press. http://dx.doi.org/10.1093/0198774508.001.0001

Kwiatkowski, D., Phillips, P. C. B., Schmidt, P., \& Shin, Y. (1992). Testing the Null Hypothesis of Stationarity Against the Alternative of a Unit Root: How sure are we that Economic Series have a Unit Root? Journal of Econometrics, 54, 159-178. http://dx.doi.org/10.1016/0304-4076(92)90104-Y

Marquez, J., \& McNeilly, C. (1988). Income and Price Elasticities for Exports of Development Countries. Review of Economic and Statistics, 70(12), 306-314. http://dx.doi.org/10.2307/1928315

Muscatelli, V. A., Srinivasan, T. G., \& Vines, D. (1992, November). Demand and Supply Factors in the Determination of NIE Exports: A Simultaneous Error-Correction Model for Hong Kong. Economic Journal, 102, 1467-1477. http://dx.doi.org/10.2307/2234801

Nguyen, D. T. (1989). The Demand for LDC Exports of Manufactures: Estimates from Hong Kong: A comment. Economic Journal, 99, 461-466. http://dx.doi.org/10.2307/2234037

Okpara, G. C. (2010). The Effect of Financial Liberalization on Selected Macroeconomic Variables: Lessons from Nigeria. The International Journal of Applied Economics and Finance, 4(2), 53-61. http://dx.doi.org/10.3923/ijaef.2010.53.61

Onafowora, O. A., \& Owoye, O. (2008). Exchange Rate Volatility and Export Growth in Nigeria. Applied Economics, 40, 1547-1556. http://dx.doi.org/10.1080/00036840600827676

Osterwald-Lenum, M. (1992, August). A Note with Quantiles of the Asymptotic Distributions of the Maximum Likelihood Cointegration Ranks Test Statistics: Four Cases. Oxford Bulletin of Economics and Statistics, 54, 461-472. http://dx.doi.org/10.1111/j.1468-0084.1992.tb00013.x

Park, J. Y. (1992). Canonical Cointegration Regressions. Econometrica, 60, 119-143. http://dx.doi.org/10.2307/2951679

Park, J. Y., \& Choi, B. (1988). A New Approach to Testing for a Unit Root. Working Paper No.88-23, Department of Economics, Cornell University, Ithaca, NY.

Pesaran, H. M., Shin, Y., \& Smith, R. J. (2001). Bounds Testing Approaches to the Analysis of Level Relationships. Journal of Applied Economics, 16(3), 289-326. http://dx.doi.org/10.1002/jae.616

Pesaran, H., \& Pesaran, B. (1997). Working with Microfit 4.0: Interactive Econometric Analysis. Cambridge, United Kingdom, Camfit Data Ltd.

Phillips, P. C. B., \& Hansen, B. E. (1990). Statistical Inference in Instrumental Variables Regression with I (1) Processes. The Review of Economic Studies, 57(1), 99-125. http://dx.doi.org/10.2307/2297545

Riedel, J. (1988). The Demand for LDC Exports of Manufactures: Estimates from Hong Kong. The Economic Journal, 98, 138-148. http://dx.doi.org/10.2307/2233515

Riedel, J. (1989). The Demand for LDC Exports of Manufactures: Estimates from Hong Kong: A Rejoinder. The Economic Journal, 99, 467-470. http://dx.doi.org/10.2307/2234038

Shin, Y., Yu, B., \& Greenwood-Nimmo, M. J. (2011). Modelling Asymmetric Cointegration and Dynamic Multipliers in a Nonlinear ARDL Framework. Retrieved from http://papers.ssrn.com/sol3/papers.cfm?abstract_id=1807745

Stock, J. H., \& Watson, M. (1993). A Simple Estimator of Cointegrating Vectors in Higher Order Integrated Systems. Econometrica, 61(4), 783-820. http://dx.doi.org/10.2307/2951763

Tavlas, G. S., \& Swamy, P. A. V. B. (1997). Macroeconomic Policies and World Financial Integration. In M. U. Fratianni, D. Salvatore, \& H. Von Itazen (Eds.), Macroeconomic Policy in Open Economics (pp. 248-280). Westport, Connecticut, USA: Greenwood Press.

Wickens, M. R., \& Breusch, T. S. (1988). Dynamic Specification, Long-run and the Estimation of Transformed Regression Models. The Economic Journal, 98, 189-205. http://dx.doi.org/10.2307/2233314

Yinusa, D. O. (2008). Between Dollarization and Exchange-Rate Volatility Nigeria's Portfolio diversification Option. Journal of Policy Modeling, 30, 811-826. http://dx.doi.org/10.1016/j.jpolmod.2007.09.007

\section{Notes}

Note 1. Non-linear version has been purposed by Shin, Yu, and Greenwood-Nimmo (2011). 
Note 2. The use of the real effective exchange rate (REER) enables us to avoid issues concerning the possibility of dominance of numeraire currency. This is so because REER is an average (weighted) of bilateral exchange rates and averaging is more likely to eliminate the effects of the base country's experience on the index, hence it allows consideration of several trading partners. Work by Onafowora and Owoye (2008) uses the real exchange rate of Nigeria and the United States.

Note 3. For interpretational reasons, the conditional variance employed by others is in squared units, whereas, the standard deviation is in original units.

Note 4. Monte Carlo evidence by Gregory (1994) suggests that instances of conflicting test results are likely to occur in cointegration analyses because of sharp power differences that empirical conditions such as sample size, lag order, and number of regressors differ. In light of this, Gregory notes that it is of considerable practical importance to calculate and report several tests for cointegration in applied studies.

Note 5. D86 captures Nigerian government adoption of Structural Adjustment Program (SAP) and its associated flexible exchange rate as well as financial liberalization measures. Nevertheless, the military government abandoned SAP in 1994 because of continuing currency depreciation as well as inflation. Thus 1994 to 1997 was period one of guided deregulation. D98 recognizes the abandonment of fixed official exchange rate by fiat mechanism and the indirect management of nominal exchange rate through official intervention. Note that in 1999 world oil prices began to rise resulting in accumulation ii the level of reserves, see Yinsua (2008) and Okpara (2010) as well as several Central Bank of Nigeria reports.

Note 6. The following discussion is based on Choudhry (1999).

Note 7. For space considerations, the results obtained using our second measure of exchange rate volatility are similar to those reported above. The only difference is that coefficient on the volatility is biased downward.

Note 8 . The negative intercept of -4.75 does not indicate an incorrect sign. Given that the regressand is is a logarithm, the estimated intercept is also a logarithm, therefore, it is necessary to take the antilog of this value by raising e to the power of -4.75 . The result will yield 0.00865 .

Note 9 . The dummy variable is one for the observation $1980: 1$ through $1986: 4$ and zero otherwise.

Appendix A. Johansen Cointegration Test

\begin{tabular}{|c|c|c|c|c|c|c|c|c|c|}
\hline & \multirow[b]{2}{*}{$H_{0}$} & \multicolumn{4}{|c|}{ Maximal Eigenvalue } & \multicolumn{4}{|c|}{ Trace Statistics } \\
\hline & & $\mathrm{r}=0$ & $\mathrm{r} \leq 1$ & $\mathrm{r} \leq 2$ & $r \leq 3$ & $\mathrm{r}=0$ & $\mathrm{r} \leq 1$ & $\mathrm{r} \leq 2$ & $\mathrm{r} \leq 3$ \\
\hline & $H_{a}$ & $\mathrm{R}=1$ & $\mathrm{r}=2$ & $r=3$ & $\mathrm{r}=4$ & $\mathrm{r} \geq 1$ & $\mathrm{r} \geq 2$ & $r \geq 3$ & $\mathrm{r} \geq 4$ \\
\hline Statistics & & 34.35 & 14.62 & 6.86 & 1.73 & 57.56 & 23.21 & 8.59 & 1.73 \\
\hline $95 \% \mathrm{CV}$ & & 27.14 & 21.07 & 14.90 & 8.18 & 48.28 & 31.53 & 17.59 & 8.18 \\
\hline$\lambda$ & & 0.28 & 0.13 & 0.06 & 0.02 & 0.28 & 0.13 & 0.06 & 0.02 \\
\hline
\end{tabular}

Notes. The VAR order is five and $\lambda$ is eigenvalue.

\section{Appendix B}

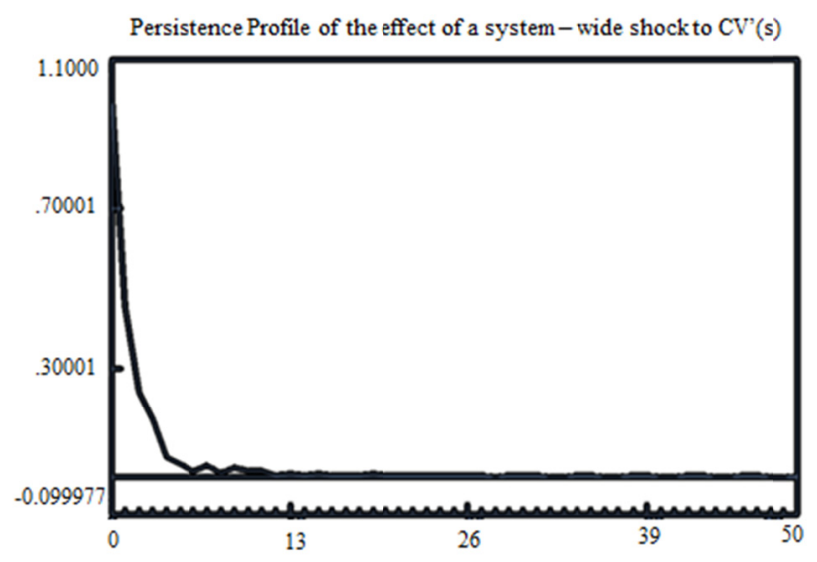

Figure B1. Persistence profile of the cointegretion equation 


\section{Appendix C. Alternative Estimates of the Cointegration Equations}

\begin{tabular}{lccc}
\hline Method & $\boldsymbol{w}_{\boldsymbol{t}}$ & $\boldsymbol{p}_{\boldsymbol{t}}$ & $\boldsymbol{\sigma}\left(\boldsymbol{h}_{\boldsymbol{t}}\right)$ \\
\hline Johansen & -3.15 & -0.74 & -3.27 \\
& $(8.00)$ & $(8.79)$ & $(10.71)$ \\
Stock-Watson & 3.14 & -0.63 & -3.04 \\
& $(3.78)$ & $(0.63)$ & $(7.85)$ \\
Phillips-Hansen & 3.04 & -0.64 & -2.59 \\
& $(6.96)$ & $(6.33)$ & $(6.98)$ \\
Park CCR & 3.07 & -0.60 & -2.33 \\
& $(6.73)$ & $(5.75)$ & $(6.19)$ \\
Bewley-Wickens Breusch & 3.53 & -0.69 & -2.86 \\
& $(5.69)$ & $(5.07)$ & $(5.50)$ \\
\hline
\end{tabular}

Note. The values in parentheses beneath the estimated coefficients are absolute t-values,except the Johansen estimator where it is the chi-square statistics.

\section{Copyrights}

Copyright for this article is retained by the author(s), with first publication rights granted to the journal.

This is an open-access article distributed under the terms and conditions of the Creative Commons Attribution license (http://creativecommons.org/licenses/by/3.0/). 